\title{
Development of Rapid Immune-gold Strip Kit for On-Site Diagnosis of Tomato spotted wilt virus
}

\author{
* Corresponding author \\ Tel : +82-31-290-6236 \\ Fax: +82-31-290-6259 \\ E-mail:viroid73@gmail.com
}

Received September 24, 2013

Revised January 27, 2014

Accepted March 4, 2014

\author{
Ju-Yeon Yoon ${ }^{1}$, Gug-Seoun $\mathrm{Choi}^{2}$, In-Sook $\mathrm{Cho}^{2}$ and Seung-Kook Choi ${ }^{2 *}$ \\ 'Department of Horticulture, Biotechnology and Landscape, Seoul Women's University, Seoul 139-774, \\ Korea \\ ${ }^{2}$ Virology Unit, Department of Horticultural Environment, National Institute of Horticultural and Herbal \\ Science, Rural Development Administration, Suwon 441-440, Korea
}

\begin{abstract}
A rapid, user-friendly and simple immune-chromatographic dipstick kit named 'rapid immune-gold strip' (RIGS) kit was developed in a novel single strip format to detect on-site detection of Tomato spotted wilt virus (TSWV). Immunoglobulin G (lgG) from polyclonal antisera raised in rabbits against TSWV was purified through proteinA affinity chromatography and then the purified TSWV-IgG was conjugated to colloidal gold nano-particles which served as a test line on nitrocellulose membrane. Protein A that non-specifically binds to TSWV antibody was used as a control line on the same strip. The diagnosis process with the TSWV-RIGS involves simply grinding the suspect plant sample in a bag that contains the extraction buffer and inserting the strip the bag. Results can be seen in 2-5 minutes. The flow of the complexes of gold particles coated with TSWV-lgG and a crude sap from TSWV-infected pepper, tobacco and tomato plants resulted in intensive color formed on the test lines proportional to the concentrations of TSWV. The RIGS-TSWV kit did not show any cross-reactions against other tomato-infecting viruses unrelated to TSWV. These results indicate that the TSWV-RIGS kit is highly sensitive and is not required for laboratory training and experience prior to testing. The TSWV-RIGS kit is suitable for on-site detection of suspect TSWV-infected plants as well as for laboratory diagnosis.
\end{abstract}

Keywords: Detection, Diagnosis, IgG, Rapid Immune-Gold Strip, On-site, Tomato spotted wilt virus

\section{Introduction}

Plant virus infection is a major factor in crop yield and has been responsible for causing severe losses in production of many vegetables such as pepper and tomato. Tomato spotted wilt virus (TSWV) is the type species of the genus Tospovirus within the family (of primarily arthropod-borne) Bunyaviridae. TSWV particles have a lipid envelope containing the virally encoded glycoproteins $\mathrm{Gn}$ and $\mathrm{Gc}$ ( $\mathrm{n}$ and $\mathrm{c}$ refer to the $\mathrm{N}$ - and $\mathrm{C}$ terminal topology, respectively, within the precursor protein), a rather unique feature among plant viruses, reflecting the requirement for uptake and replication of the virus in its insect vector (Wijkamp et al., 1993). Virus particles harbor a tripartite negative and ambisense RNA genome that, in association with the nucleocapsid protein $(\mathrm{N})$ and the viral RNA-dependent RNA polymerase (L), forms infectious ribonucleoproteins (RNPs) (Goldbach and Peters, 1996). TSWV is spread in a propagative

Research in Plant Disease

The Korean Society of Plant Pathology

pISSN 1598-2262, elSSN 2233-9191 manner by at least seven thrips species (Ullman et al., 1993; Wijikamp et al., 1993). Among those, Frankliniella occidentalis (western flower thrips) and Frankliniella fusca (tobacco thrips) are the most efficient vectors. Unlike the other arthropodborne members of the Bunyaviridae, old second instar larvae and adults can become transmitters of TSWV only if the virus is acquired by the thrips in the first instar larval stage. The midgut epithelial cells of thrips are the initial site of TSWV entry and infection. After replication in the midgut, TSWV moves to muscle fibers surrounding the midgut and then migrates to the salivary glands (German et al., 1992; Goldbach and Peters, 1996).

TSW causes economic losses to a wide of economically important crops and particularly to vegetables such as peppers and tomatoes in Korea (Cho et al., 2005; Choi et al., 2010; Kim et al., 2004). Various immune-assay methods have been reported for detection of TSWV, such as enzyme-linked immunosorbent assay (Adam et al., 1996; de Avila et al., 1990; Gonsalves and Trujillo, 1986; Huguenot et al., 1990; Sherwood et al., 1989), dotimmunobinding assay (Wang and Gonsalves, 1990), immunecapture Reverse-transcription (RT)-PCR (Fuji et al., 1998; Fukuta 
et al., 2004; Weekes et al., 1996), RT-PCR (Dewey et al., 1996; Mumford et al., 1996; Okuda and Hanada, 2001; Sharma et al., 2000), and real-time RT-PCR (Boonham et al., 2002; Debreczeni et al., 2011; Robert et al., 2000). However, this kind of determination required some expensive equipment, for example, a microplate reader. As colloidal gold has been widely used in Immuneassay for large molecular, the nano-colloidal gold particles could replace the enzyme to be labeled to antibody in detection of plant viruses, such as commercial kits from Agdia corporation. Compared with enzyme immuno-assay, the determination by colloidal gold-based immuno-assay can be completed rapidly in one step. When the antibody labeled with colloidal gold particles is combined with the corresponding antigen, the colored immune-reactant can be visually detected. This user-friendly format possesses several advantages, such as a very short time for obtaining test results, long-term stability over a wide range of climates and relative in expense. These characteristics make it ideally suited for on-site testing by untrained personnel.

The emerging research field of non-instrumental measurements of multiple residues provides the possibilities for simultaneous detection of TSWV from pepper and other crops. As a rapid, on-site, easy and low-cost method, rapid immunegold strip kit (RIGS) method plays a role in the determination of TSWV. In the RIGS, colloidal gold-nano-particles (AuNPs) for TSWV detection is commonly used as signal material. AuNPs are visible and can be detected with naked eyes. Therefore, the RIGS combined with AuNPs has been widely used.

The goal of this study was to develop a rapid and simple detection method that was based on one step membrane-based competitive colloidal gold immuno-assay, which named RIGS. Colloidal gold immuno-assay has been developed and applied increasingly in various research fields such as for the detection of insecticides, toxins, hormones, animal viruses, and bacteria (Kranthi et al., 2009; Lai et al., 2009; Li et al., 2013; Moon et al., 2012; Wang et al., 2005; Xu et al., 2012; Zhang et al., 2006; Zein et al., 2006). In this paper, we describe the development of onestep colloidal gold-based assays (named RIGS combined with AuNPs) for the detection of TSWV from a variety of horticultural crops including tomato and pepper.

\section{Materials and Methods}

Chemicals. Nitro-cellulose membranes were obtained from Millipore (USA). Semi-rigid polyethylene sheets, sample wick, absorbent pad used in the development of immuno-chromatographic, and adhesive tape were purchased from Whatman ${ }^{\circledast}$ (USA). Filter paper, Endosulfan-diol, colloidal gold ( $40 \mathrm{~nm}$ ), ovalbumin, protein A, Freund's complete and incomplete adjutants, analytical grade buffer chemicals, and all other reagents used in RIGS production and protein conjugation were purchased from Sigma-Aldrich (USA).

Antibody production. TSWV isolate KP (TSWV-KP) from pepper was propagated in Nicotiana rustica after mechanical inoculation with TSWV-KP particles (Kim et al., 2004). For TSWV purification, the systemic leaves of the inoculated $N$. tabacum plants were harvested after 14 days inoculation and the leaf tissues were used for TSWV purification, as described previously (Joubert et al., 1974). The purified TSWV-KP particles were verified using SDS-PAGE analysis, according to standard protocol (Sambrook et al., 1989). Polyclonal antibodies were produced in rabbits by immunization with the purified TSWV-KP conjugates. For the first immunization, the immunogen (0.1 mg) was suspended in $2 \mathrm{ml}$ of $0.5 \times$ phosphate buffer saline (PBS), emulsified with $2 \mathrm{ml}$ Freund's complete adjuvant and injected subcutaneously in two rabbits for each immunogen. Four booster dose immunizations were given at monthly intervals after the first immunization using $0.1 \mathrm{mg}$ TSWV virions in $2 \mathrm{ml}$ of $0.5 \times$ PBS buffer emulsified with Freund's incomplete adjuvant. About 10-12 $\mathrm{ml}$ serum was collected from the marginal ear vein, 14 days after each booster. Sera that exhibited a strong immunogenic response were further purified by affinity chromatography using ProteinA affinity chromatography columns and dialyzed against $10 \mathrm{mM}$ sodium phosphate buffer ( $\mathrm{pH}$ 7.2), according to manufacturer's instructions (PALL, USA).

Antibody labelling. The affinity purified immunoglobulin ( $\mathrm{lgG}$ ) was conjugated to colloidal gold $(40 \mathrm{~nm})$ according to the methods, as described previously (Horisberger, 1989). The optimal concentration of antibody for conjugation with colloidal gold was determined by titrating aliquots of diluted lgG with colloidal gold. The purified lgG was diluted to a concentration of $0.1 \mathrm{mg} / \mathrm{ml}$ in sodium phosphate buffer ( $1 \mathrm{mM}, \mathrm{pH} 7.0)$. The $\mathrm{pH}$ of colloidal gold solution and the diluted $\mathrm{lg} \mathrm{G}$ was adjusted to $\mathrm{pH} 8.0$ with $0.1 \mathrm{M} \mathrm{KCO}_{3}$. Ten aliquots of variable concentrations $(0.01-0.1 \mathrm{mg} / \mathrm{ml})$ of the diluted lgG were prepared in $0.2 \mathrm{ml}$ sodium phosphate buffer. Then, a series of diluted lgG solution was added separately to $1 \mathrm{ml}$ of the colloidal-gold solution, as described previously (Li et al., 2013). After incubating the mixture for $10 \mathrm{~min}, 0.1 \mathrm{ml}$ of $10 \% \mathrm{NaCl}$ was added to the tubes and the absorbance was measured at $520 \mathrm{~nm}$. The least amount of protein required to stabilize the colloidal gold was identified from the abscissa in the curve drawn from the concentration and the absorbance. Aliquot (approximately $10 \mathrm{ml}$ ) of purified lgG $(0.1 \mathrm{mg} / \mathrm{ml})$ was added drop-wise to $100 \mathrm{ml}$ of colloidal-gold solution ( $\mathrm{pH} \mathrm{8.0)}$ followed by the addition of $10 \mathrm{ml}$ of filtered $10 \%$ bovine serum albumin (BSA), $\mathrm{pH} 8.0$ with gentle stirring for $20-25 \mathrm{~min}$. The solution was incubated for $10 \mathrm{~min}$ at $25^{\circ} \mathrm{C}$ and centrifuged at $15,000 \mathrm{~g}$ for $30 \mathrm{~min}$ at $4^{\circ} \mathrm{C}$. The supernatant was discarded and the loose precipitate of gold conjugate was re-suspended in $5 \mathrm{ml}$ conjugate dilution buffer (1 mM Tris, 1\% ovalbumin, $1 \%$ sucrose, and $0.03 \%$ sodium azide) and stored at $4^{\circ} \mathrm{C}$, as described previously (Lai et al., 2010).

Preparation of RIGS kit. A novel format (Fig. 1) was de- 


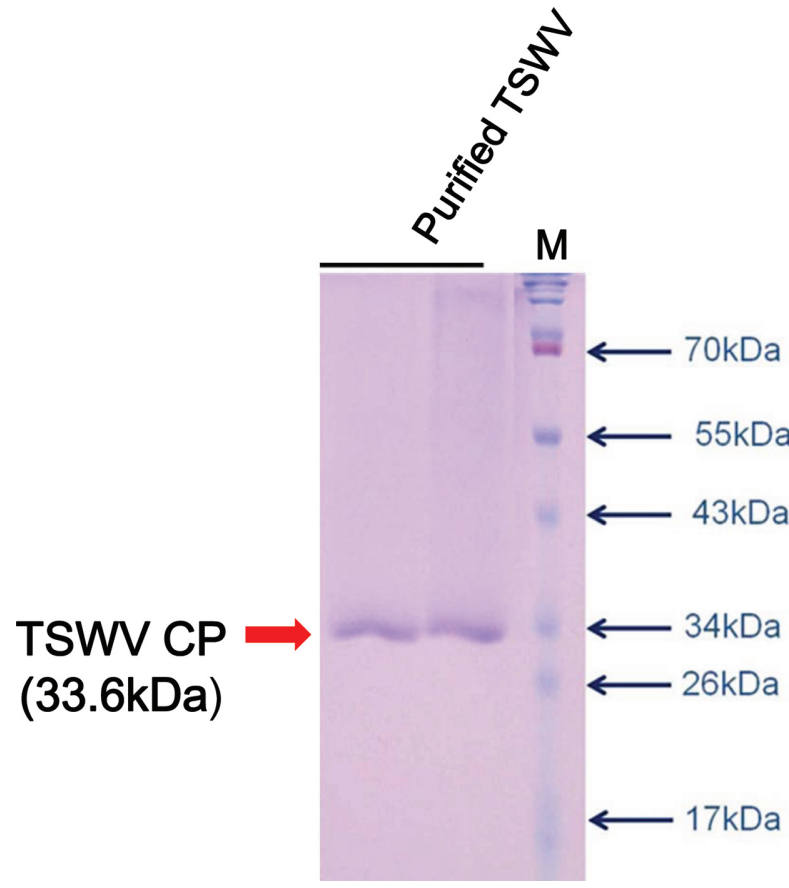

Fig. 1. SDS-PAGE analysis of purified Tomato spotted wilt virus (TSWV) virions. TSWV particles were purified from Nicotiana rustica. Protein size marker (Bio-Rad, USA) shown on the right was used for determination of molecular mass of TSWV capsid proteins (red arrow).

signed for RIGS kit, so that it enables the detection of TSWV on a single strip. The colloidal-gold-conjugated solution of antisera raised against TSWV was mixed in equal quantities and applied on $26 \times 1.7 \mathrm{~cm}$ conjugate pads (Standard 14) and dried under dry air for 10-15 min. TSWV IgG-BSA conjugate was diluted in $20 \mathrm{mM}$ sodium phosphate buffer, ( $\mathrm{pH} \mathrm{8.0)}$ containing $1 \%$ sucrose to a final concentration of $2 \mathrm{mg} / \mathrm{ml}$ and applied as a $0.5 \mathrm{~mm}$ thick, $26 \mathrm{~cm}$ line, centrally at $1.25 \mathrm{~cm}$ from the top and bottom ends on one side of a $2.5 \times 26 \mathrm{~cm}$ nitrocellulose plastic backed membrane strip, using a locally fabricated airbrush device (Innovative Biosciences, India). Nitrocellulose membrane was cut into sections $(2.5 \mathrm{~cm} \times 26 \mathrm{~cm})$. Test line was coated with TSWV-lgG conjugate, which was applied to each membrane in $150 \mathrm{\mu g} / \mathrm{ml}$ TSWV using TLC conjugate sampler (Sambrook et al., 1989). The distance between the test line and control line was $6 \mathrm{~mm}$. The test strips were dried at $37^{\circ} \mathrm{C}$ for $30 \mathrm{~min}$. TSWV lgGBSA conjugate was diluted in $1 \mathrm{mM}$ Tris-HCl buffer ( $\mathrm{pH}$ 8.0) containing containing $1 \%$ sucrose to a final concentration of $3 \mu \mathrm{g} /$ $\mathrm{ml}$ and applied as a $1 \mathrm{~mm}$ thick, $26 \mathrm{~cm}$ line, at $0.5 \mathrm{~cm}$ from the top end of the membrane. The membrane was dried at $3^{\circ} \mathrm{C}$ under a dry wind blower for 10-15 min and blocked with $10 \mathrm{mM}$ potassium phosphate buffer $(\mathrm{pH} 7.5)$ containing $0.25 \%$ BSA and $1.0 \%$ sucrose. The membrane was dried at $37^{\circ} \mathrm{C}$ under a dry wind blower for 10-15 min and washed twice with $10 \mathrm{mM}$, sodium phosphate buffer ( $\mathrm{pH}$ 7.2) before drying it for 10-15 min at $50^{\circ} \mathrm{C}$. A polyethylene plastic sheet $(26 \times 8 \mathrm{~cm})$ of $0.2 \mathrm{~mm}$ thickness was coated with acrylic adhesive on one side and the $2.5 \mathrm{~cm}$ wide membrane was placed centrally at a spacing of 1.5 $\mathrm{cm}$ from the top and $4 \mathrm{~cm}$ from the bottom end of the sheet. The conjugate coated glass-fiber pad was placed on the lower end of the membrane, so as to overlap $2 \mathrm{~mm}$ on it. A filter pad was placed to overlap $2 \mathrm{~mm}$ on the lower end of the conjugate release pad to act as sample pad and another pad (CF4) was placed to overlap $2 \mathrm{~mm}$ on the upper end of the membrane to act as absorbent pad. The assembly was cold-laminated using an $8 \mathrm{~cm}$ wide transparent adhesive tape. The laminated 26 $\times 8 \mathrm{~cm}$ assembly was cut into lateral-flow strips of $8 \times 0.4 \mathrm{~cm}$. The strips were stored in an airtight plastic bottle containing a desiccant pack.

Extraction of TSWV-infected sample. Leaf tissues of pepper, tobacco, and tomato plants infected by TSWV were extracted with $5 \mathrm{ml}$ of $0.5 \mathrm{XPBS}$ ( $\mathrm{pH}$ 7.4) solution in a tissue grinder (Agdia, USA). Then he crude sap itself or supernatant after brief centrifugation of crude sap was used for the specificity of TSWVRIGS kit.

\section{Results and Discussion}

TSWV-KP was successfully purified from leaf tissues of $N$. rustica, showing denatured capsid proteins of TSWV-KP were detected on SDS-PAGE gel. The molecular mass of TSWV-KP was approximately $34 \mathrm{KDa}$ (Fig. 1). Polyclonal sera specific to TSWV were produced from rabbit and the lgG specific to TSWV was further purified using Protein A affinity chromatography from sera. The concentration of TSWV-lgG was $1.0 \mathrm{mg} / \mathrm{ml}$. In the production of AuNPs conjugated with TSWV-lgG, the particle size is inversely proportional to the sodium citrate volume. In the TSWV-lgG antibody-AuNP conjugation, the antibody was absorbed on the AuNP surface. The effects of $\mathrm{pH}$ values on the conjugation were studied by evaluating the absorbance between $400 \mathrm{~nm}$ and $650 \mathrm{~nm}$. Also, the main purpose of the assay was to allow visual evaluation, so it was only used as a qualitative assay to detect contamination at a threshold level. As the $\mathrm{KCO}_{3}$ concentration increased, the maximum absorption wavelength increased up to the optimal concentration and then decreased (data not shown). The definition of the optimal concentration of TSWV-antibody was the one that gave the required visibility and the best sensitivity. During antibody

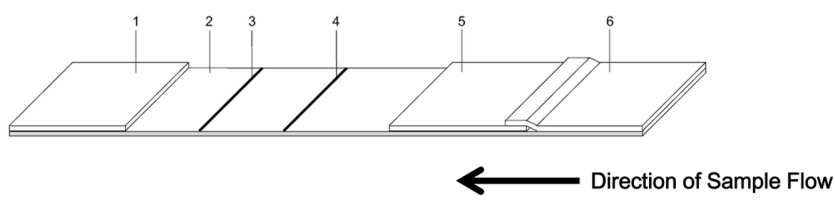

Fig. 2. Schematic diagram of rapid immune-gold strip format. Legends: 1: Absorption pad, 2: Nitrocellulose membrane, 3: Protein A as a control line, 4: Virus detection line, 5: Conjugate pad containing a mixture of colloidal-gold labeled IgG raised against TSWV, 6: Sample pad. Direction of sample flow was indicated as an arrow at the bottom. 


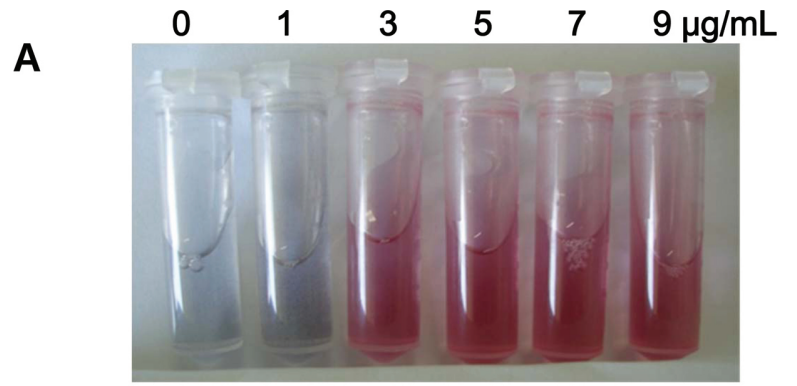

B

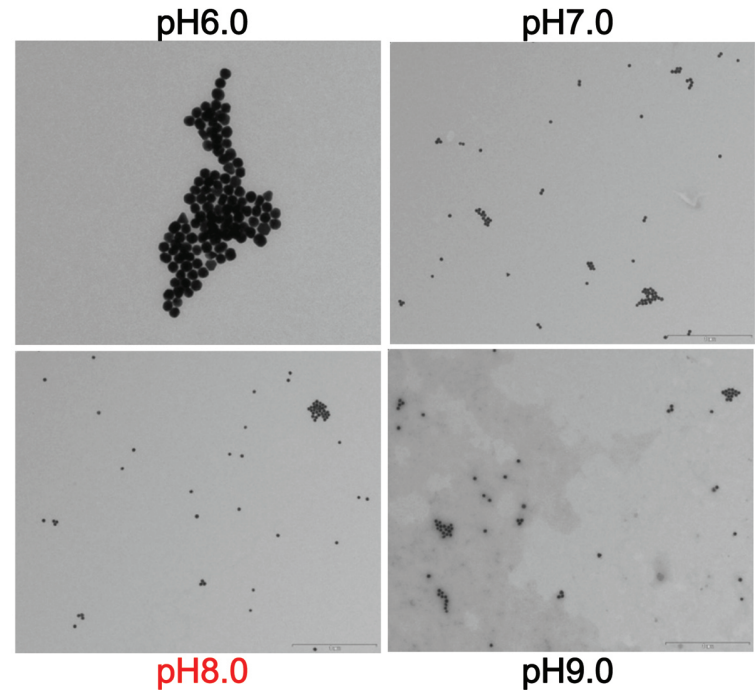

Fig. 3. Optimization of experimental conditions for preparation of colloidal gold nano-particles (AuNPs) conjugated to polyclonal Tomato spotted wilt virus (TSWV) immunoglobulin G (lgG). A: Optimal concentration of TSWV-lgG binds to AuNPs was indicated on the top of photograph, B: Optimal pH condition (red) was determined, based on distribution of TSWV-lgG-AuNPs under transmission electron microscope (TEM). Aggregates of TSWV-lgG-AuNPs look like black dots under TEM.

concentration optimization, the minimal stable polyclonal lgG concentration form antibody-AuNP conjugation was firstly designed and evaluated (Fig. 2), and then the optimal concentration was studied. Optimal immune-reagent concentration was selected as a clear color appearing in the negative control with the shortest time, and comparison of the intensity of color among samples and control could be easily distinguished by eye. The optimal concentration for polyclonal TSWV-lgG to AuNPs was $3 \mu \mathrm{g} / \mathrm{ml}$ (Fig. 3A). It is known that the amount of antibody and conjugates should be keep low enough to achieve good sensitivity, but it should be sufficient to provide an acceptable signal (Xu et al., 2012). Next, the amount of $0.1 \mathrm{M} \mathrm{NaCl}$ added to the AuNPs solution was in the range of $1-10 \mu \mathrm{l} / \mathrm{ml}$ for TSWV to determine the optimal pH of TSWV lgG for the stable color detection with AuNPs. Transmission electron microscopy showed that AuNPs conjugated with TSWV-lgG were evenly distributed at pH 8.0 (Fig. 3B). The results suggest that $3 \mu \mathrm{g}$ of TSWV-lgG is sufficient for $1 \mathrm{ml}$ of AuNPs and the optimal conjugation between TSWV-lgG and AuNP is done at pH8.0.

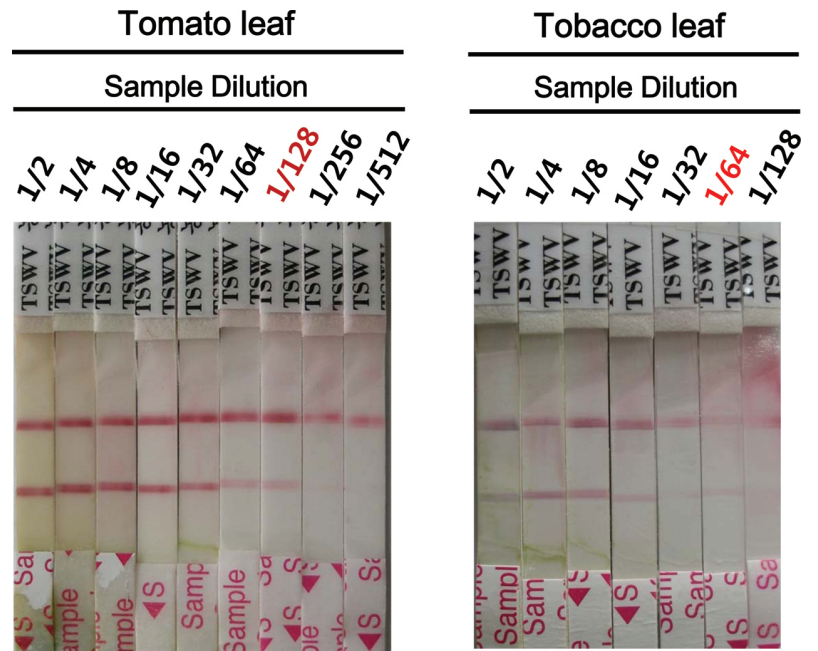

Fig. 4. End-point dilution assay with Tomato spotted wilt virus (TSWV)rapid Immune-gold strip (RIGS) kit for detection limitation of viral concentrations. A series of diluted TSWV-infected samples were prepared from initial sap of tomato and tobacco leaves $(0.1 \mathrm{~g} / \mathrm{ml}$, leaf weight/extraction buffer volume). Dilution ratio was indicated on the top of photograph. End-point dilution for TSWV detection using TSWV-RIGS kit was indicated (red).

In general, the analytical performance of the RIGS strip is affected by many parameters, such as the type and pore size of the membrane, blocking buffer and immune-reagent amount. In this work, blocking buffers for the conjugate and sample pads were evaluated to study its effect on polyclonal lgG specific to TSWV and analytes. In addition, the blocking buffers with the BSA or ovalbumin were evaluated to get the optimal blocking buffer. The results show that $10 \mathrm{mM}$ PBS (pH 7.4) containing $0.25 \% \mathrm{BSA}, 1 \%$ sucrose and $0.03 \% \mathrm{NaN}_{3}$ was chosen as the optimal blocking buffer for the conjugate pads.

The competitive RIGS strip for TSWV detection was defined as the lowest TSWV concentration producing the color on the test line significantly weaker than that of the negative control strip. A serial end-point dilution of crude saps from TSWV-infected tomato and tobacco leaves was used for the sensitivity of the RIGS. The sample pad of RIGS strip was soaked in aliquot of crude saps, showing that the color intensity was readily shown after $5 \mathrm{~min}$ (Fig. 4). The intensity of the test lines decreased with the dilution of TSWV virion concentration. It is clearly shown that TSW in plant tissues can be successful detected as amount as $7.83 \times 10^{-4} \mathrm{~g} / \mathrm{ml}$ of tomato tissue and $1.57 \times 10^{-3} \mathrm{~g} / \mathrm{ml}$ of tobacco tissue using the developed RIGS kit (Fig. 4). The reliability of the RIGS strip was evaluated by performing the TSWV detection in pepper as well as other host species infected by TSWV or mock (healthy). Methods for extraction of TSWV-infected plants were the same as described before. TSWV infection were successfully detected from pepper cultivars, tomato and tobacco plants infected by TSWV (Fig. 4 and data not shown), suggesting that the RIGS is useful for TSWV detection from economically important 


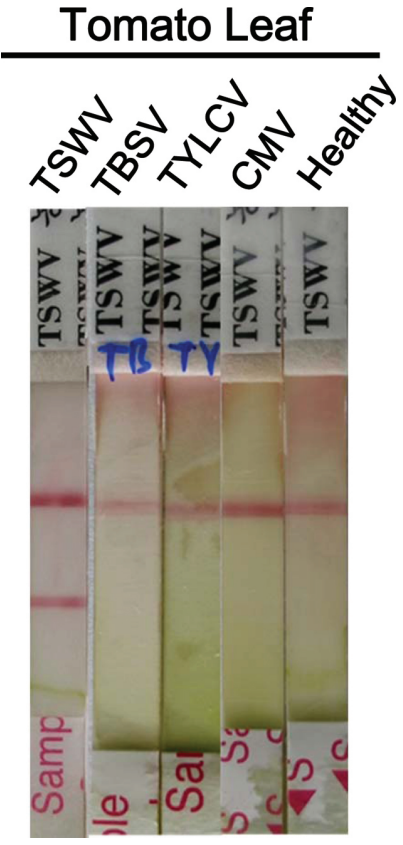

Fig. 5. Reliability and specificity assays of Tomato spotted wilt virus (TSWV)-rapid Immune-gold strip (RIGS) kit. RIGS strip kit was used for detections of TSWV on pepper cultivars, tobacco and tomato. For specificity of TSWV-RIGS strips, tomato leaf tissues infected by Tomato bush stunt virus (TBSV), Cucumber mosaic virus (CMV) or Tomato yellow leaf curl virus (TYLCV) were assayed on the RIGS strips as challenging viruses, respectively. Healthy tomato leaf tissues were used as a negative control and tomato leaf tissues infected by TSWV were used as a positive control.

crops, such as pepper and tomato (Kim et al., 2004; Cho et al., 2005; Choi et al., 2010). To determine whether the TSWV-RIGS strip reacts with unrelated plant viruses, representative viruses infecting pepper cultivars were evaluated for specificity of the RIGS strips. As shown in Fig. 5, the RIGS strips did not cross-react to Tomato bush stunt virus, Cucumber mosaic virus and Tomato yellow leaf curl virus that cause severe damage to tomato production. These results confirm the high specificity and reliability of the RIGS for TSWV detection in tomato and other crops (Fig. 5). The stability of the RIGS strip assay was evaluated by comparing the analysis of TSWV-infected crude sap before and after the strip storage (Daughtrey, 1996). The strips prepared from the same batch were stored at $4^{\circ} \mathrm{C}$ under dry conditions. After 6 months of the storage of the strips, color intensity and detection sensitivity did not show significant differences from those using the fresh strips (data not shown), indicating that the RIGS strip assay was highly stable at the room temperature conditions.

\section{Acknowledgement}

This work was supported by a grant from Basic Research Program of National Institute of Horticultural and Herbal Science, Rural Development Administration, Republic of Korea.

\section{References}

Adam, G., Peters, D. and Goldbach, R. W. 1996. Serological comparison of tospovirus isolates using polyclonal and monoclonal antibodies. Acta Hort. 431:135-158.

De Avila, A. C., Huuenot, C., Resende, R., Kitajima, E. W., Goldbach, R. W. and Peters, D. 1990. Serological differentiation of 20 isolates of Tomato spotted wilt virus. J. Gen. Virol. 71: 2801-2807.

Boonham, N., Smith, P., Walsh, K., Tame, J., Morris, J., Spence, N., Bennison, J. and Barker, I. 2001. The detection of Tomato spotted wilt virus (TSWV) in individual thrips using real time fluorescent RTPCR (TaqMan). J. Virol. Meth. 101: 37-48.

Brittlebank, C. C. 1919. Tomato diseases. J. Agri. Victoria 27: 231-235.

Cho, J. D., Kim, J. S., Kim, J. Y., Kim, J. H., Lee, S. H., Choi, G. S., Kim H. R. and Chung, B. N. 2005. Occurrence and symptoms of Tomato spotted wilt virus on vegetables in Korea. Res. Plant Dis. 11: 213216. (In Korean)

Choi, H. S., Lee, S. H., Kim, M. K., Kwak, H. R., Kim, J. S., Choi, J. D. and Choi, G. S. 2010. Occurrence of virus diseases on major crops in 2009. Res. Plant Dis. 16: 1-9. (In Korean)

Daughtrey, M. L. 1996. Detection and identification of tospoviruses in greenhouses. Acta Hort. 431: 90-98.

Debreczeni, D. E., Ruiz-Ruiz, S., Aramburu, J., López, C., Belliure, B., Galipienso, L., Soler, S. and Rubio, L. 2011. Detection, discrimination and absolute quantitation of Tomato spotted wilt virus isolates using real time RT-PCR with TaqMan(®)MGB probes. J. Virol. Meth. 176: 32-37.

Dewey, R. A., Semorile, L. C. and Grau, O. 1996. Detection of Tospovirus species by RT-PCR of the N-gene and restriction enzyme digestions of the products. J. Virol. Meth. 56: 19-26.

Fuji, S., Ohishi, K. and Nakamae H. 1998. Detection of Tomato spotted wilt virus in chrysanthemum by immunocapture RT-PCR assay. Proc. Kansai Plant Prot. 40: 111-112.

Fukuta, S., Ohishi, K., Yoshida, K., Mizukami. Y., Ishida. A. and Kanbe, M. 2004. Development of immunocapture reverse transcription loop-mediated isothermal amplification for the detection of Tomato spotted wilt virus from chrysanthemum. J. Virol. Meth. 121:49-55.

German, T. L., Ullman, D. E. and Moyer, J. W. 1992. Tospoviruses: Diagnosis, molecular biology, phylogeny and vector relationships. Ann. Rev. Phytopathol. 30: 315-348.

Goldbach, R. W. and Peters, D. 1996. Molecular and biological aspects of tospoviruses. The Bunyaviridae. Plenum Press, New York, USA. 129-157 pp.

Gonsalves, D. and Trujillo, E. 1986. Tomato spotted wilt virus in papaya and detection of the virus by ELISA. Plant Dis. 70: 501-506.

Horisberger, M., 1989. Quantitative aspects of labeling colloidal gold with proteins. In: Verkleij, A. J., Leunissen, J. L. M. (Eds.), Immunogold Labelling in Cell Biology. CRC Press, Boca Raton, USA.

Huguenot, C., van den Dobbelsteen, G., de Haan, P., Wagemakers, C. A. M., Drost, G. A., Osterhaus, A. D. M. E. and Peters, D. 1990. Detection of Tomato spotted wilt virus using monoclonal antibodies and riboprobes. Arch. Virol. 110: 47-62.

Joubert, J. J., Hahn, J. S., von Wechmar, M. B. and van Regenmortel, M. H. V. 1974. Purification and properties of Tomato spotted wilt 
virus. Virology 57: 11-19.

Kim, J. H., Choi, G. S., Kim, J. S. and Choi, J. K. 2004. Characterization of Tomato spotted wilt virus from paprika in Korea. Plant Pathology J. 20: 297-301.

Kranti, K. R., Davis, M., Mayee, C. D. Russell, D. A., Shulka, R. M., Satija, U., Kshirsagar, M., Shiware, D. and Kranthi, S. 2009. Development of a colloidal-gold based lateral-flow immuno-assay kit for 'quality-control' assessment of pyrethroid and endosulfan formulations in a novel single strip format. Crop Prot. 28: 428434.

Lai, C., Zheng, G. M., Huang, D. L., Feng, C. L., Hu, S., Su, F. F., Zhao, M. H., Huang, C. and Zhen, W. 2010. Detection based on immunogold labeling technique and its expected applications in composting. Chinese J. Anal. Chem. 38: 909-914.

Lai, W., Fung, D. Y. C., Xu, Y., Liu, R. and Xiong, Y. 2009. Development of a colloidal gold strip for rapid detection of ochratoxin A with mimotope peptide. Food Control 20: 791-795.

Li, X., Li, P., Zhang, Q., Li, R., Zhang, W., Zhang, Z., Ding, X. and Tang, X. 2013. Multi-component immunochromatographic assay for simultaneous detection of aflatoxin B1, orchratoxin A and zearalenone in agro-food. Biosens. Bioelectron. 49: 426-432.

Moon, J., Kim, G. and Lee, S. 2012. A gold nanoparticle and aflatoxin B1-BSA conjugates based lateral flow assay method for the analysis of aflatoxin B1. Materials 5: 634-643.

Mumford, R. A., Barker, I. and Wood, K. R. 1996. An improved method for the detection of Tospoviruses using the polymerase chain reaction. J. Virol. Meth. 57: 109-115.

Okuda, M. and Hanada, K. 2001. RT-PCR for detecting five distinct Tospovirus species using degenerate primers and dsRNA template. J. Virol. Meth. 96: 149-156.

Roberts, C. A., Dietzgen, R. G., Heelan, L. A. and Maclean, D. J. 2000. Real-time RT-PCR fluorescent detection of Tomato spotted wilt virus. J. Virol. Meth. 88: 1-8.

Sambrook, J., Fritsch, E. F. and Maniatis, T. 1989. Molecular Cloning. A Laboratory Manual (2nd ed.), Cold Spring Harbor Laboratory Press, Cold Spring Harbor, N.Y., USA.

Sharma, M., Thomas, J. E. and Dietzgen, R. G. 2000. Development of a multiplex immunocapture PCR with colourimetric detection for viruses of banana. J. Virol. Meth. 89: 75-88.

Sherwood, J. L., Sanborn, M. R., Keyser, G. C. and Myers, L. D. 1989. Use of monoclonal antibodies in detection of Tomato spotted wilt virus. Phytopathol. 79: 61-64.

Ullman, D. E., German, T. L., Sherwood, J. L., Westcot, D. M. and Cantone, F. A. 1993. Tospovirus replication in insect vector cells: Immunocytochemical evidence that the nonstructural protein encoded by the S RNA of Tomato spotted wilt tospovirus is present in thrips vector cells. Phytopathol. 83: 456-463.

Wang, M. and Gonsalves, D. 1990. ELISA detection of various Tomato spotted wilt virus isolates using specific antisera to structural proteins of the virus. Plant Dis. 74: 154-158.

Wang, S., Zhang, C., Wang, J., and Zhang, Y. 2005. Development of colloidal gold-based flow-through and lateral-flow immunoassays for the rapid detection of the insecticide carbaryl. Anal. Chim. Acta. 546: 161-166.

Weekes, R., Barker, I. and Wood, K. R. 1996. An RT-PCR test for the detection of Tomato spotted wilt tospovirus incorporating immunocapture and colorimetric estimation. J. Phytopathol. 144: 575-580.

Wijkamp, I., van Lent, J., Kormelink, R., Goldbach, R. and Peters, D. 1993. Multiplication of Tomato spotted wilt virus in its insect vector, Frankliniella occidentalis. J. Gen. Virol. 74: 341-349.

Xu, T., Xu, Q. G., Li, H., Wang, J., Li, Q. X., Shelver, W. L. and Li, J. 2012. Strip-based immuno-assay for the simultaneous detection of the neonicotinoid insecticides imidacloprid and thiamethoxam in agricultural products. Talanta 101: 85-90.

Zhang, C., Zhang, Y. and Wang, S. 2006. Development of multianalyte flow-through and lateral-flow assays using gold particles and horseradish peroxidase as tracers for the rapid determination of carbaryl and endosulfan in agricultural products. J. Agric. Food Chem. 54: 2502-2507.

Zein, H. S., Nakazawa, M., Ueda, M., Ohkie, S. T., Takashima, Y. and Miyatake, K. 2006. Detection and diagnosis of Cucumber mosaic virus infected plants using monoclonal antibodies by enzymelinked immunosorbent assays. Eco-Engineering 18: 15-20. 